Article

\title{
Prediction of Carcass Traits of Hair Sheep Lambs Using Body Measurements
}

\author{
Emmanuel Bautista-Díaz ${ }^{1}$, Jesús Alberto Mezo-Solis ${ }^{1}$, José Herrera-Camacho ${ }^{2}$, \\ Aldenamar Cruz-Hernández ${ }^{1}$, Armando Gomez-Vazquez ${ }^{1}$, Luis Orlindo Tedeschi ${ }^{3}$ (D), \\ Héctor Aarón Lee-Rangel ${ }^{4}$ (D) Einar Vargas-Bello-Pérez ${ }^{5, * \mathbb{D}}$ and Alfonso Juventino Chay-Canul ${ }^{1, * \mathbb{D}}$ \\ 1 División Académica de Ciencias Agropecuarias, Universidad Juárez Autónoma de Tabasco, Carretera \\ Villahermosa-Teapa Km 25, Villahermosa 86280, Tabasco, Mexico; emmanuel_09_27@hotmail.com (E.B.-D.); \\ jesusmezo.solis@gmail.com (J.A.M.-S.); ingaldecruz@gmail.com (A.C.-H.); dragv2@hotmail.com (A.G.-V.) \\ 2 Instituto de Investigaciones Agropecuarias y Forestales, Universidad Michoacana de San Nicolás de Hidalgo, \\ Carretera Morelia-Zinapécuaro Km 9.5, El Trébol, Tarímbaro 58893, Michoacán, Mexico; josheca@gmail.com \\ 3 Department of Animal Science, Texas A\&M University, College Station, TX 77843-2471, USA; \\ luis.tedeschi@tamu.edu \\ 4 Facultad de Agronomía y Veterinaria, Universidad Autónoma de San Luis Potosí, San Luis Potosí 78000, \\ S.L.P., Mexico; hector.lee@uaslp.mx \\ 5 Department of Veterinary and Animal Sciences, Faculty of Health and Medical Sciences, University of \\ Copenhagen, Grønnegårdsvej 3, DK-1870 Frederiksberg C, Denmark \\ * Correspondence: evargasb@sund.ku.dk (E.V.-B.-P.); aljuch@hotmail.com (A.J.C.-C.)
}

Received: 19 June 2020; Accepted: 22 July 2020; Published: 27 July 2020

check for updates

Simple Summary: Some authors have reported that the use of body measurements (BMs) could be a useful tool for predicting carcass characteristics in sheep. Hair sheep breeds have been adopted for lamb production in the tropical regions of Latin America. Among these, Pelibuey and Katahdin breeds and their crosses have shown great reproductive capacity and adaptation, contributing to improving the productive efficiency of flocks in tropical production systems. However, few studies have been carried out on this breeds to define its BMs correctly, and little work has been found using BMs to predict the carcass characteristics in different physiological stages.

Abstract: The present study was designed to evaluate the relationship between the body measurements (BMs) and carcass characteristics of hair sheep lambs. Twenty hours before slaughter, the shrunk body weight (SBW) and BMs were recorded. The BMs involved were height at withers (HW), rib depth (RD), body diagonal length (BDL), body length (BL), pelvic girdle length (PGL), rump depth (RuD), rump height (RH), pin-bone width (PBW), hook-bone width (HBW), abdomen width (AW), girth (GC), and abdomen circumference (AC). After slaughter, the carcasses were weighed and chilled for $24 \mathrm{~h}$ at $1^{\circ} \mathrm{C}$, and then were split by the dorsal midline. The left-half was dissected into total soft tissues (muscle + fat; TST) and bone (BON), which were weighed separately. The weights of viscera and organs (VIS), internal fat (IF), and offals (OFF—skin, head, feet, tail, and blood) were also recorded. The equations obtained for predicting SBW, HCW, and CCW had an $r^{2}$ ranging from 0.89 to 0.99 , and those for predicting the TST and BON had an $r^{2}$ ranging from 0.74 to 0.91 , demonstrating satisfactory accuracy. Our results indicated that use of BMs could accurately and precisely be used as a useful tool for predicting carcass characteristics of hair sheep lambs.

Keywords: body measurements; carcass traits; prediction; linear traits; modelling 


\section{Introduction}

Alternative or indirect methods for the determination of the carcass and body composition of livestock have recently been studied [1,2]. Among the most common indirect variables to determine the carcass and body composition of sheep are body weight (BW) and body condition score (BCS). On the other hand, direct methods involve the separation and dissection of an animal's body and the determination of its physical and chemical components [1,2]. However, these latter methods are extremely laborious, time-consuming, and costly because of the large number of personnel and laboratory analyses required in addition to being wasteful, as half of the carcass is subsequently discarded [1-4].

Indirect methods include the prediction of carcass and body composition based on parameters easily obtained [1] through ultrasound [4-6], computed tomography, dual x-ray absorptiometry (DEXA), digital image analysis or body measurements [6-9]. Some of these methods, such as computerised tomography, magnetic resonance, and DEXA are limited to developed countries due to the cost of acquiring the necessary equipment and the need for specialised, professionally trained personnel; also, these methods can be time-consuming [3,9-11]. Ultimately, the selected method for predicting carcass traits and body composition should be based on several factors, including the cost, ease of adoption and prediction accuracy regardless of the sex, age, or diet of animals [1].

In vivo body measurements (BMs) may be of greater interest under commercial production conditions because they enable the assessment of carcass traits or the prediction of commercial cuts with few or no additional costs to producers $[8,10,12]$. Due to their low cost and practicality, BMs have long been used as an indicator of animal type and potential of production $[13,14]$ or as a predictor of BW, body mass index, and carcass traits [15-17]. However, the use of BMs to estimate growth and carcass and body composition in hair sheep is limited [8]. Hence, the present study was aimed to evaluate the relationship between body measurements (BMs) and carcass traits in hair sheep lambs.

\section{Materials and Methods}

\subsection{Location and Animals Management}

The animals were treated in accordance with the guidelines and regulations for animal experimentation of the División Académica de Ciencias Agropecuarias, Universidad Juárez Autónoma de Tabasco (ID project PFI: UJAT-DACA-2015-IA-02). The experiment was carried out at the El Rodeo commercial farm $\left(17^{\circ} 84^{\prime \prime} \mathrm{N}, 92^{\circ} 81^{\prime \prime} \mathrm{W} ; 10 \mathrm{~m}\right.$ a.s.l.) located at $\mathrm{km} 14$ of the Villahermosa-Jalapa highway, Tabasco, Mexico. The study was performed on 66 hair lambs, including 39 Pelibuey and 27 Katahdin sheep. Of these, 36 were male and 30 were female; 30 were single lambings and 36 were double lambings. Ewes and lambs were housed together in individual pens of $1.5 \times 2 \mathrm{~m}$. They were held for 56 days prior with access to food and water. The offspring did not have direct access to the ewes' feeders. Lambs were slaughtered at 56 days of age.

\subsection{Body Measurements}

For each lamb, the following body measurements (BMs) were recorded $24 \mathrm{~h}$ prior to slaughter. The BMs were taken as described previously by Bautista-Diaz et al. [8]: (1) height at withers (HW), (2) rib depth (RD), (3) body diagonal length (BDL), (4) body length (BL), (5) pelvic girdle length (PGL), (6) rump depth (RuD), (7) rump height (RH), (8) pin bone width (PBW), (9) hook bone width (HBW), (10) abdomen width (AW), (11) girth circumference (GC), and (12) abdomen circumference (AC) (Figure 1). Flexible fiberglass tape $\left(\operatorname{Truper}^{\circledR}\right)$ and large $65-\mathrm{cm}$ calipers (Haglof ${ }^{\circledR}$ ) were used to perform the measurements. BMs were expressed in $\mathrm{cm}$, and the measurements taken were previously related to carcass composition [8]. 

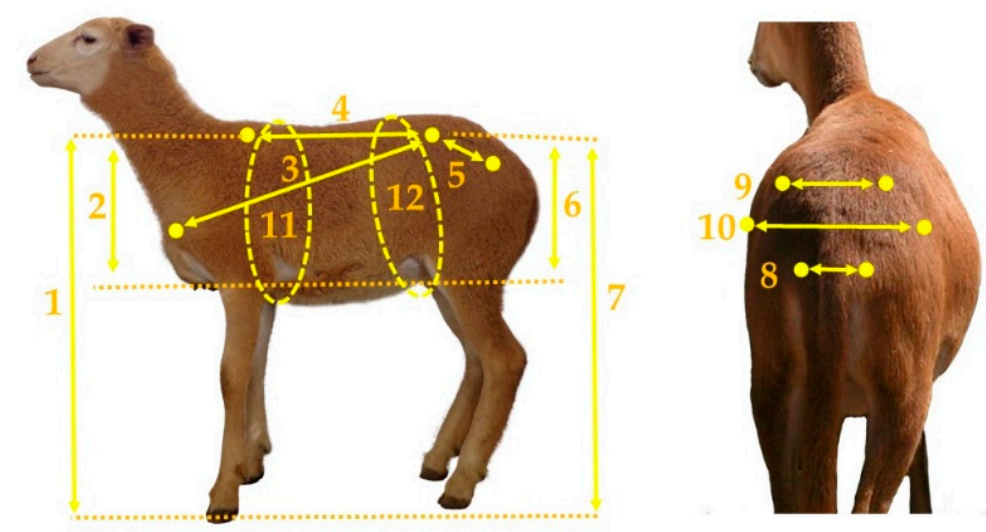

Figure 1. Body measurements taken in hair sheep lambs. (1) height at withers, (2) rib depth, (3) body diagonal length, (4) body length, (5) pelvic girdle length, (6) rump depth, (7) rump height, (8) pin bone width, (9) hook bone width, (10) abdomen width, (11) girth circumference, and (12) abdomen circumference. The lamb used as a reference was 56 days of age and $14.2 \mathrm{~kg}$ of live weight.

\subsection{Slaughter of Animals}

Lambs were fasted for 20 hours before slaughtering in order to record shrunk body weight (SBW). Lambs were slaughtered according to the Mexican Official Standard NOM-033-ZOO-1995 for the humane slaughter of animals. After slaughter, the carcasses were weighed (hot carcass weight; HCW). Then, they were split by the dorsal midline into two halves and kept at $1{ }^{\circ} \mathrm{C}$. Then, after $24 \mathrm{~h}$, carcasses were reweighed (cold carcass weight; $\mathrm{CCW}$ ), and the left halves were dissected into total soft tissues (muscle + fat; TSTs) and bone tissues (BONs), which were each weighed separately. The weights of the tissues dissected from the left halves of the carcass were doubled to reflect the total carcass weight. The viscera and organs (VIS: liver, heart, kidneys, lungs, rumen and empty intestines, gall bladder, and spleen) were removed and weighed. Internal fat (IF) was grouped as pelvic fat (around kidneys and the pelvic region) or as fat around the gastrointestinal tract (omental and mesenteric). The gastrointestinal tract (GIT) was weighed full and empty. The empty BW (EBW) was calculated as the slaughter body weight minus the GIT contents. Finally, the weight of the waste parts (skin, head, feet, tail, and blood; OFF) was recorded.

\subsection{Statistical Analyses}

A descriptive statistical analysis was performed using the PROC MEANS procedure in SAS, North Carolina, USA [18]. Correlation coefficients of Pearson's among variables were estimated using the PROC CORR procedure in SAS SAS, North Carolina, USA [18]. Regressions were developed using the PROC REG procedure in SAS, North Carolina, USA [18]. The STEPWISE option and Mallow's Cp were used in the SELECTION statement to select the variables included in the model. The goodness of fit of the developed models was evaluated by the determination coefficients $\left(r^{2}\right)$ and root mean squared error (RMSE).

Based on the recommendations of Tedeschi [19], several additional statistics were used to assess the predictability of the equations, including the coefficients of determination $\left(r^{2}\right)$, mean squared error (MSE), standard deviation (SD), mean squared error of prediction (MSEP) and root of the MSEP (RMSEP), which account for the distance between predicted and true values. The regressions were evaluated according to the null hypothesis $\left(\mathrm{H}_{0}\right)$ that states that $b_{0}$ is equal to zero and $b_{1}$ is equal to one and the alternative hypothesis $\left(\mathrm{H}_{\mathrm{A}}\right)$ that is not $\mathrm{H}_{0}$. A non-rejection of the null hypothesis means that the model accurately explained the variation that occurred in the dataset. The precision was assessed by the evaluation of the $r^{2}$ of the linear regression of $Y$ (i.e., observed) on $X$ (i.e., predicted) as described by Fonseca et al. [20] and Morales-Martinez et al. [4]. The mean bias (MB), as described by Cochran and Cox [21], was used as a representation of the average inaccuracy of the model. The modelling 
efficiency factor (MEF), which represents the proportion of variation explained by the line $Y=X$, was used as an indicator of goodness of fit [22,23]. The coefficient of model determination (CD) was used to assess variance in the predicted data. The bias correction factor $(\mathrm{Cb})$, a component of the concordance correlation coefficient (CCC) [24], was used as an indicator of deviation from the identity line, and the CCCs were also used as a reproducibility index to account for accuracy and precision. High accuracy and precision were assumed when the coefficients were $>0.80$, and low accuracy and precision were assumed when the coefficients were $<0.50$. These calculations were performed in the Model Evaluation System proposed by Tedeschi [19].

\section{Results and Discussion}

The descriptive statistics of the BMs and carcass characteristics are reported in Table 1. The SBW ranged from 6.08 to $16.85 \mathrm{~kg}$ (coefficient of variation $(\mathrm{CV})$ of $23.9 \%$ ). With respect to the carcass weights (HCW and CCW), the HCW ranged from $2.85 \mathrm{~kg}$ to $8.56 \mathrm{~kg}$, with a CV around $26 \%$ for both parameters. The weights of carcass tissues presented high variability (Table 1): The CVs of the TST and $\mathrm{BON}$ weights were $30.5 \%$ and $18.4 \%$, respectively, and even greater variation was observed in the IF weight, which had a CV $>64$. Internal fat is considered to be the most variable body component. Several authors have stated that body fat varies due to factors such as breed, sex, age and state of maturity $[8,17,25,26]$. Finally, low to moderate variation was observed in the BMs (6.44-19.216\%).

Table 1. Descriptive analyses of the body measurements of live animals ( $n=66$ suckling lambs).

\begin{tabular}{|c|c|c|c|c|c|}
\hline Variable & Description & Mean \pm SD & Maximum & Minimum & CV (\%) \\
\hline \multicolumn{6}{|c|}{ Body measurements } \\
\hline SBW & Shrunk body weight $(\mathrm{kg})$ & $10.78 \pm 2.58$ & 16.85 & 6.08 & 23.93 \\
\hline EBW & Empty body weight (kg) & $9.64 \pm 2.33$ & 14.88 & 5.18 & 24.18 \\
\hline HW & Height at withers $(\mathrm{cm})$ & $48.47 \pm 3.46$ & 56.00 & 34.00 & 7.14 \\
\hline $\mathrm{RD}$ & Rib depth $(\mathrm{cm})$ & $17.96 \pm 2.68$ & 26.00 & 14.00 & 14.92 \\
\hline BDL & Body diagonal length $(\mathrm{cm})$ & $36.68 \pm 3.13$ & 44.00 & 29.00 & 8.53 \\
\hline BL & Body length $(\mathrm{cm})$ & $29.29 \pm 2.61$ & 35.00 & 23.00 & 8.91 \\
\hline PGL & Pelvic girdle length $(\mathrm{cm})$ & $13.55 \pm 2.14$ & 17.00 & 10.00 & 15.79 \\
\hline $\mathrm{RuD}$ & Rump depth (cm) & $15.20 \pm 2.92$ & 23.00 & 8.00 & 19.21 \\
\hline $\mathrm{RH}$ & Rump height (cm) & $48.00 \pm 3.09$ & 55.00 & 41.00 & 6.44 \\
\hline PBW & Pin bone width $(\mathrm{cm})$ & $5.72 \pm 1.08$ & 8.00 & 3.50 & 18.88 \\
\hline HBW & Hook bone width $(\mathrm{cm})$ & $8.84 \pm 1.18$ & 12.50 & 6.60 & 13.35 \\
\hline $\mathrm{AW}$ & Abdomen width (cm) & $10.92 \pm 1.58$ & 14.00 & 7.00 & 14.47 \\
\hline GC & Girth circumference (cm) & $51.22 \pm 4.63$ & 61.00 & 34.00 & 9.04 \\
\hline $\mathrm{AC}$ & Abdomen circumference $(\mathrm{cm})$ & $51.33 \pm 5.63$ & 65.00 & 40.00 & 10.97 \\
\hline \multicolumn{6}{|c|}{ Carcass characteristics } \\
\hline $\mathrm{HCW}$ & Hot carcass weight $(\mathrm{kg})$ & $5.28 \pm 1.36$ & 8.56 & 2.85 & 25.76 \\
\hline CCW & Cold carcass weight $(\mathrm{kg})$ & $5.02 \pm 1.33$ & 8.09 & 2.68 & 26.49 \\
\hline TST & Total soft tissues (muscle + fat), (kg) & $3.54 \pm 1.08$ & 5.99 & 1.71 & 30.51 \\
\hline $\mathrm{BON}$ & Bone $(\mathrm{kg})$ & $1.46 \pm 0.27$ & 2.25 & 0.93 & 18.49 \\
\hline IF & Internal fat $(\mathrm{kg})$ & $0.28 \pm 0.18$ & 0.79 & 0.02 & 64.29 \\
\hline VIS & Organs and viscera (kg) & $1.26 \pm 0.32$ & 2.25 & 0.71 & 25.40 \\
\hline OFF & Offals $(\mathrm{kg})$ & $2.61 \pm 0.54$ & 3.98 & 1.71 & 20.69 \\
\hline
\end{tabular}

$\mathrm{SD}=$ standard deviation; $\mathrm{CV}$ : coefficient of variation.

The PBW and RD were not correlated with IF and VIS, respectively $(P>0.05)$. Nonetheless, the other MB have an $r$ that varied from 0.24 to $0.84(P<0.05)$ (Table 2$)$. The regression equations developed to predict the carcass characteristics are presented in Table 3: For both HCW and CCW, three equations were obtained, with an $r^{2}$ ranging from 0.89 to 0.99 (Table 2); in these models, the AC, RD, and PGL were included $(P<0.05)$. For the prediction of TST, BON, VIS, and IF, the equations had an $r^{2}$ ranging from 0.47 to 0.98; in these models, the GC, RD, HBW, PGL, AC, and RuD were included. For the prediction of OFF weight, only one the equation was fitted, with an $r^{2}$ of 0.94 ; in this case, only SBW was included as a predictor. Notably, SBW accounted for a high proportion of the variation in the carcass traits evaluated in the present study (47\% to 99\%; Table 3). Previously, the importance of SBW as a predictor was reported for cattle [6]. Notably, the SBW accounted for $47 \%$ to $99 \%$ of the variation in the evaluated carcass traits (Table 2). 
Table 2. Pearson correlations coefficients of between body measurements and carcass traits of suckling hair lambs ${ }^{1}$.

\begin{tabular}{|c|c|c|c|c|c|c|c|c|c|c|c|c|c|c|c|c|c|c|c|c|}
\hline & EBW & HCW & CCW & TST & BON & IF & VIS & OFF & HW & RD & BL & BDL & PGL & RuD & RH & GC & AC & PBW & HBW & AW \\
\hline SBW & 0.98 & 0.95 & 0.92 & 0.90 & 0.86 & 0.68 & 0.84 & 0.96 & 0.68 & $0.32 * *$ & 0.75 & 0.79 & 0.49 & 0.49 & 0.62 & 0.87 & 0.84 & 0.47 & 0.67 & 0.72 \\
\hline EBW & & 0.96 & 0.94 & 0.93 & 0.85 & 0.73 & 0.80 & 0.95 & 0.68 & $0.34^{* *}$ & 0.72 & 0.77 & 0.46 & 0.46 & 0.61 & 0.88 & 0.81 & 0.45 & 0.66 & 0.70 \\
\hline HCW & & & 0.96 & 0.95 & 0.84 & 0.76 & 0.72 & 0.93 & 0.65 & 0.40 & 0.70 & 0.76 & $0.38^{* *}$ & $0.38^{* *}$ & 0.58 & 0.84 & 0.74 & 0.40 & 0.67 & 0.70 \\
\hline CCW & & & & 0.98 & 0.88 & 0.75 & 0.69 & 0.90 & 0.65 & $0.36^{* *}$ & 0.67 & 0.72 & $0.38^{* *}$ & $0.37^{* *}$ & 0.57 & 0.81 & 0.68 & 0.33 ** & 0.64 & 0.65 \\
\hline TST & & & & & 0.83 & 0.77 & 0.64 & 0.88 & 0.63 & $0.34 * *$ & 0.65 & 0.70 & $0.37^{* *}$ & $0.34 *$ & 0.54 & 0.81 & 0.66 & $0.31 *$ & 0.64 & 0.65 \\
\hline BON & & & & & & 0.54 & 0.69 & 0.85 & 0.68 & 0.41 & 0.63 & 0.66 & $0.33^{* *}$ & $0.39^{* *}$ & 0.62 & 0.70 & 0.69 & $0.38^{* *}$ & 0.61 & 0.61 \\
\hline IF & & & & & & & 0.45 & 0.61 & 0.45 & $0.29 *$ & 0.39 & 0.56 & $0.24 *$ & 0.27 * & $0.30 *$ & 0.63 & 0.41 & $0.17^{\mathrm{ns}}$ & 0.53 & 0.51 \\
\hline VIS & & & & & & & & 0.82 & 0.55 & $0.12^{\text {ns }}$ & 0.72 & 0.62 & 0.49 & 0.58 & 0.51 & 0.72 & 0.83 & 0.50 & $0.47^{*}$ & 0.57 \\
\hline OFF & & & & & & & & & 0.64 & $0.31^{* *}$ & 0.72 & 0.76 & 0.48 & $0.48 *$ & 0.56 & 0.83 & 0.79 & $0.46 *$ & 0.63 & 0.69 \\
\hline HW & & & & & & & & & & 0.50 & 0.64 & 0.67 & $0.25 *$ & $0.21^{\mathrm{ns}}$ & 0.77 & 0.66 & 0.66 & 0.42 & 0.59 & 0.47 \\
\hline $\mathrm{RD}$ & & & & & & & & & & & $0.22^{\mathrm{ns}}$ & 0.37 * & $0.039 * *$ & $-0.36^{* *}$ & 0.60 & 0.41 & $0.34^{* *}$ & $0.19^{\mathrm{ns}}$ & 0.44 & 0.39 \\
\hline BL & & & & & & & & & & & & 0.60 & 0.45 & $0.38^{* *}$ & 0.57 & 0.69 & 0.70 & 0.49 & 0.53 & 0.57 \\
\hline BDL & & & & & & & & & & & & & $0.31^{* *}$ & $0.25 *$ & 0.59 & 0.74 & 0.72 & 0.41 & 0.53 & 0.63 \\
\hline PGL & & & & & & & & & & & & & & 0.68 & $0.07^{\mathrm{ns}}$ & 0.40 & $0.37^{* *}$ & $0.24 *$ & $0.20^{\mathrm{ns}}$ & $0.22^{\mathrm{ns}}$ \\
\hline $\mathrm{RuD}$ & & & & & & & & & & & & & & & $0.11^{\text {ns }}$ & $0.30 *$ & 0.41 & 0.39 & $0.34^{* *}$ & 0.31 ** \\
\hline RH & & & & & & & & & & & & & & & & 0.63 & 0.62 & 0.46 & 0.50 & 0.45 \\
\hline GC & & & & & & & & & & & & & & & & & 0.81 & 0.47 & 0.63 & 0.70 \\
\hline $\mathrm{AC}$ & & & & & & & & & & & & & & & & & & 0.55 & 0.64 & 0.69 \\
\hline PBW & & & & & & & & & & & & & & & & & & & $0.39 * *$ & $0.39 * *$ \\
\hline HBW & & & & & & & & & & & & & & & & & & & & 0.64 \\
\hline
\end{tabular}

${ }^{1}$ Correlations followed by no superscript indicate $P<0.001$; ${ }^{* *}: P<0.01 ; *: P<0.05$; ns: non-significant. 
Table 3. Regression equations for prediction of carcass traits in suckling hair lambs using body measurements ${ }^{1}$.

\begin{tabular}{|c|c|c|c|c|c|}
\hline No. Equation & Equation & $\mathbf{n}$ & RMSE & $r^{2}$ & $P$ \\
\hline \multicolumn{6}{|l|}{$E B W$} \\
\hline 1 & EBW $(\mathrm{kg})=0.89\left( \pm 0.004^{* * *}\right) \times \mathrm{SBW}$ & 66 & 0.34 & 0.99 & $<0.0001$ \\
\hline 2 & $\mathrm{EBW}(\mathrm{kg})=1.29\left( \pm 0.46^{* *}\right)+0.97\left( \pm 0.03^{* * *}\right) \times \mathrm{SBW}-0.04\left( \pm 0.01^{* *}\right) \times \mathrm{AC}$ & 66 & 0.33 & 0.98 & $<0.0001$ \\
\hline 3 & $\operatorname{EBW}(\mathrm{kg})=0.91\left( \pm 0.02^{* * *}\right) \times \mathrm{SBW}+0.04\left( \pm 0.01^{* * *}\right) \times \mathrm{GC}-0.04\left( \pm 0.01^{* * *}\right) \times \mathrm{AC}$ & 65 & 0.29 & 0.99 & $<0.0001$ \\
\hline \multicolumn{6}{|c|}{ ( } \\
\hline 4 & $\mathrm{HCW}(\mathrm{kg})=0.49\left( \pm 0.004^{* * *}\right) \times \mathrm{SBW}$ & 66 & 0.40 & 0.99 & $<0.0001$ \\
\hline 5 & $\mathrm{HCW}(\mathrm{kg})=1.78\left( \pm 0.52^{* *}\right)+0.62\left( \pm 0.03^{* * *}\right) \times \mathrm{SBW}-0.06\left( \pm 0.01^{* *}\right) \times \mathrm{AC}$ & 66 & 0.37 & 0.92 & $<0.0001$ \\
\hline 6 & $\mathrm{HCW}(\mathrm{kg})=1.13\left( \pm 0.46^{*}\right)+0.61\left( \pm 0.03^{* * *}\right) \times \mathrm{SBW}+0.06\left( \pm 0.02^{* * *}\right) \times \mathrm{RD}-0.07\left( \pm 0.01^{* * *}\right) \times \mathrm{AC}$ & 65 & 0.30 & 0.95 & $<0.0001$ \\
\hline \multicolumn{6}{|c|}{ 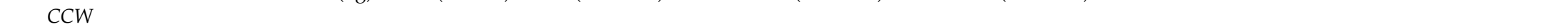 } \\
\hline 7 & $\mathrm{CCW}(\mathrm{kg})=0.47\left( \pm 0.005^{* * *}\right) \times \mathrm{SBW}$ & 66 & 0.50 & 0.99 & $<0.0001$ \\
\hline 8 & $\mathrm{CCW}(\mathrm{kg})=2.45\left( \pm 0.63^{* * *}\right)+0.63\left( \pm 0.04^{* * *}\right) \times \mathrm{SBW}-0.08\left( \pm 0.02^{* * *}\right) \times \mathrm{AC}$ & 66 & 0.45 & 0.89 & $<0.0001$ \\
\hline 9 & $\mathrm{CCW}(\mathrm{kg})=2.53\left( \pm 0.52^{* * *}\right)+0.65\left( \pm 0.03^{* * *}\right) \times \mathrm{SBW}-0.08\left( \pm 0.02^{* * *}\right) \times \mathrm{PGL}-0.07\left( \pm 0.01^{* * *}\right) \times \mathrm{AC}$ & 64 & 0.31 & 0.94 & $<0.0001$ \\
\hline \multicolumn{6}{|c|}{ (C) } \\
\hline 10 & $\operatorname{TST}(\mathrm{kg})=-0.55( \pm 0.24 *)+0.38( \pm 0.02 * * *) \times \mathrm{SBW}$ & 66 & 0.46 & 0.82 & $<0.0001$ \\
\hline 11 & $\operatorname{TST}(\mathrm{kg})=1.66\left( \pm 0.58^{* *}\right)+0.51\left( \pm 0.03^{* * *}\right) \times \mathrm{SBW}-0.07\left( \pm 0.02^{* * *}\right) \times \mathrm{AC}$ & 66 & 0.41 & 0.85 & $<0.0001$ \\
\hline 12 & $\operatorname{TST}(\mathrm{kg})=2.16\left( \pm 0.58^{* * *}\right)+0.54\left( \pm 0.04^{* * *}\right) \times \mathrm{SBW}-0.05\left( \pm 0.02^{* *}\right) \times \mathrm{RuD}-0.07\left( \pm 0.02^{* * *}\right) \mathrm{AC}$ & 66 & 0.39 & 0.87 & $<0.0001$ \\
\hline 13 & $\operatorname{TST}(\mathrm{kg})=1.52\left( \pm 0.53^{* *}\right)+0.53\left( \pm 0.03^{* * *}\right) \times \mathrm{SBW}-0.06\left( \pm 0.02^{* * *}\right) \times \mathrm{RuD}-0.07\left( \pm 0.01^{* * *}\right) \times \mathrm{AC}+0.10\left( \pm 0.05^{*}\right) \times \mathrm{HBW}$ & 65 & 0.33 & 0.91 & $<0.0001$ \\
\hline \multicolumn{6}{|c|}{ 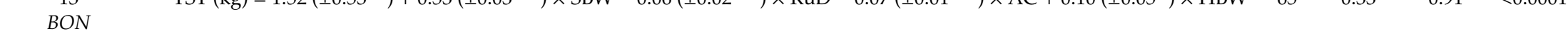 } \\
\hline 14 & $\mathrm{BON}(\mathrm{kg})=0.47\left( \pm 0.07^{* * *}\right)+0.09\left( \pm 0.01^{* * *}\right) \times \mathrm{SBW}$ & 66 & 0.14 & 0.74 & $<0.0001$ \\
\hline 15 & $\mathrm{BON}(\mathrm{kg})=0.26( \pm 0.12 *)+0.09( \pm 0.01 * * *) \times \mathrm{SBW}+0.01( \pm 0.01 *) \times \mathrm{RD}$ & 66 & 0.14 & 0.76 & $<0.0001$ \\
\hline 16 & $\mathrm{BON}(\mathrm{kg})=0.79\left( \pm 0.20^{* * *}\right)+0.12\left( \pm 0.01^{* * *}\right) \times \mathrm{SBW}+0.02\left( \pm 0.01^{* * *}\right) \times \mathrm{RD}-0.02\left( \pm 0.01^{* * *}\right) \times \mathrm{GC}$ & 64 & 0.10 & 0.86 & $<0.0001$ \\
\hline \multicolumn{6}{|c|}{ (1) } \\
\hline 17 & $\operatorname{IF~}(\mathrm{kg})=-0.24\left( \pm 0.07^{* *}\right)+0.05\left( \pm 0.01^{* * *}\right) \times \mathrm{SBW}$ & 66 & 0.14 & 0.47 & $<0.0001$ \\
\hline 18 & $\mathrm{IF}(\mathrm{kg})=0.37\left( \pm 0.17^{*}\right)+0.09\left( \pm 0.01^{* * *}\right) \times \mathrm{SBW}-0.02\left( \pm 0.01^{* * *}\right) \times \mathrm{AC}$ & 66 & 0.11 & 0.65 & $<0.0001$ \\
\hline 19 & $\mathrm{IF}(\mathrm{kg})=0.08\left( \pm 0.008^{* * *}\right) \times \mathrm{SBW}+0.01\left( \pm 0.004^{* *}\right) \times \mathrm{GC}-0.02\left( \pm 0.004^{* * *}\right) \times \mathrm{AC}$ & 64 & 0.10 & 0.90 & $<0.0001$ \\
\hline \multicolumn{6}{|c|}{ ( o } \\
\hline 20 & $\operatorname{VIS~}(\mathrm{kg})=0.11( \pm 0.002 * * *) \times \mathrm{SBW}$ & 66 & 0.17 & 0.98 & $<0.0001$ \\
\hline 21 & VIS $(\mathrm{kg})=-0.66\left( \pm 0.23^{* *}\right)+0.06\left( \pm 0.02^{* * *}\right) \times \mathrm{SBW}+0.03\left( \pm 0.01^{* * *}\right) \times \mathrm{AC}$ & 66 & 0.17 & 0.76 & $<0.0001$ \\
\hline 22 & $\operatorname{VIS}(\mathrm{kg})=-0.89\left( \pm 0.22^{* * *}\right)+0.05\left( \pm 0.01^{* *}\right) \times \mathrm{SBW}+0.02\left( \pm 0.01^{* * *}\right) \times \mathrm{RuD}+0.03\left( \pm 0.01^{* * *}\right) \times \mathrm{AC}$ & 66 & 0.14 & 0.79 & $<0.0001$ \\
\hline 23 & $\operatorname{VIS}(\mathrm{kg})=-0.53\left( \pm 0.15^{* *}\right)+0.07\left( \pm 0.01^{* * *}\right) \times \mathrm{SBW}+0.02\left( \pm 0.004^{* * *}\right) \times \mathrm{RuD}+0.02\left( \pm 0.004^{* * *}\right) \times \mathrm{AC}-0.05\left( \pm 0.02^{* *}\right) \times \mathrm{HBW}$ & 62 & 0.09 & 0.90 & $<0.0001$ \\
\hline \multicolumn{6}{|c|}{ 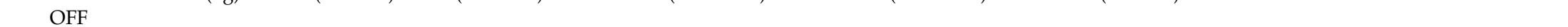 } \\
\hline 24 & $\mathrm{OFF}(\mathrm{kg})=0.41\left( \pm 0.07^{* * *}\right)+0.20\left( \pm 0.01^{* * *}\right) \times \mathrm{SBW}$ & 64 & 0.12 & 0.94 & $<0.0001$ \\
\hline
\end{tabular}

${ }^{1}$ Values within parentheses are the SEs of the parameter estimates. ${ }^{*}: P<0.05 ;{ }^{* *}: P<0.01 ; * *: P<0.001$. Intercepts not different from 0 were removed from the final equations. EBW: empty body weight (kg); HCW: hot carcass weight (kg); CCW: cold carcass weight (kg); TST: total soft tissues (muscle + fat, kg); BON: bone tissues (kg); IF: internal fat (kg); VIS: organs and viscera (kg); OFF: offals (kg); SBW: shrunk body weight (kg); AC: abdomen circumference (cm); GC: girth circumference (cm); RD: rib depth (cm); PGL: pelvic girdle length (cm); RuD: rump depth (cm); HBW: hook bone width (cm); MSE: mean square error; RMSE: root mean square error; $r^{2}$ : coefficient of determination. 
The inclusion of BMs such as GC, RD, HBW, PGL, AC, and RuD to the prediction equations improved the $r^{2}$ or reduced the RMSE (Table 2). According to previous research, BMs alone can explain between $38 \%$ and $93 \%$ of the variation in the carcass traits of ewes [8]. In hair sheep, few studies have used BMs to predict the carcass traits of animals in different physiological states. However, of these studies, it was reported that the HW of animals was a good predictor of carcass weight, true carcass yield, CCW and viscera weight $[8,27]$. Nonetheless, in the present study, the HW was not included in any model. Similarly, Hernández-Espinoza et al. [26] informed that the TST weight had a negative relationship with BL. However, in the current study, the BL had a positive association with the TST weight $(r=0.65, P<0.001)$. Nevertheless, it was not included as a predictor in any equation used to predict TST weight (Table 2), nor were any of the BMs related with body length (BL or BDL) included in the models for predicting carcass traits (Table 3). This is in agreement with the previous reports of Hernández-Espinoza et al. [27] and Bautista-Díaz et al. [8]. On the other hand, in adult Pelibuey ewes, Bautista-Díaz et al. (2017) found that GC and AC showed a good correlation with HCW and CCW in agreement with the results found for hair lambs in the present study.

Concerning other breeds of sheep, Shehata [28] reported that the GC accounted for around $72 \%$ of the variation in the carcass weights (HCW and CCW) in Barki lambs. Also, this latter author found that GC was a good predictor of the primary commercial cuts, accounting for $45 \%$ to $67 \%$ of the variation. In buffalo calves, Rashad et al. [29] found that the GC had a high correlation with all carcass characteristics except bone weight; but was the best predictor of boneless meat and carcass fat weights $\left(r^{2}=0.90,0.78\right)$. In Pelibuey ewes, Bautista-Díaz et al. [8] reported that BM can be used to predict the carcass tissue composition (in weights). Nonetheless, these authors do not recommend that their models be used for animals of the opposite sex or with distinct physiological conditions.

Finally, in regard to the evaluation of the equations (Table 4, Figure 2), all equations presented high precision $\left(r^{2}>0.90\right)$, except for Equations (16) and (19) (Table 4; Figure 2). In addition, all equations presented high accuracy $(\mathrm{Cb}>0.90$; Table 3$)$ and had a good reproducibility index and good concordance with the observed data $(\mathrm{CCC}=0.99,0.97,0.93,0.95,0.91,0.76,0.86$, and 0.97 for Equations (3)-(24), respectively). According to the MEF, all equations except for Equation (19) presented a moderate to the high efficiency of prediction (from 0.71 to 0.98 ), indicating a moderate to high concordance between the predicted and actual values. It is important to note the MEF has been reported as the best measure of concordance between observed and predicted values. Meanwhile, the CDs of the equations ranged from 0.98 to 1.16 , indicating high variability in the predicted data (Table 4; Figure 2). In this case, a model with a perfect fit would have a CD value of one, and values closer to one indicate improvement in the predictions of a model. The present values indicate an underestimation of the carcass traits, with a variation of about $16 \%$ [19], considering that a CD $>1$ indicates underprediction and a $\mathrm{CD}<1$ indicates overprediction. The main component of the MSEP for Equations (3), (6), (9), (13), (16), (19) and (24) was random error (91.1, 92.2, 76.6, 90.8, 80.1, 74.8, and 87.0, respectively), although for Equation (23), a high proportion of the MSEP was attributed to mean bias (65.10\%; Table 4, Figure 2). 
Table 4. Mean and descriptive statistics of the accuracy and precision of the equations for predicting carcass traits in suckling hair lambs using body measurements.

\begin{tabular}{|c|c|c|c|c|c|c|c|c|}
\hline Variable $^{1}$ & $\begin{array}{c}\text { Equation (3) } \\
\text { EBW }\end{array}$ & $\begin{array}{c}\text { Equation (6) } \\
\text { HCW }\end{array}$ & $\begin{array}{c}\text { Equation (9) } \\
\text { CCW }\end{array}$ & $\begin{array}{c}\text { Equation (13) } \\
\text { TST }\end{array}$ & $\begin{array}{c}\text { Equation (16) } \\
\text { BON }\end{array}$ & $\begin{array}{c}\text { Equation (19) } \\
\text { IF }\end{array}$ & $\begin{array}{c}\text { Equation (23) } \\
\text { VIS }\end{array}$ & $\begin{array}{c}\text { Equation (24) } \\
\text { OFF }\end{array}$ \\
\hline Mean & 9.64 & 5.18 & 4.88 & 3.62 & 1.42 & 0.34 & 1.11 & 2.56 \\
\hline SD & 2.24 & 1.32 & 1.28 & 1.05 & 0.25 & 0.16 & 0.28 & 0.52 \\
\hline Maximum & 15.01 & 8.54 & 8.15 & 6.13 & 2.07 & 0.75 & 1.73 & 3.78 \\
\hline Minimum & 5.57 & 2.94 & 2.64 & 1.72 & 0.96 & -0.02 & 0.61 & 1.63 \\
\hline$r^{2}$ & 0.98 & 0.95 & 0.94 & 0.91 & 0.86 & 0.66 & 0.90 & 0.94 \\
\hline $\mathrm{CCC}$ & 0.99 & 0.97 & 0.93 & 0.95 & 0.91 & 0.76 & 0.86 & 0.97 \\
\hline $\mathrm{Cb}$ & 0.99 & 0.99 & 0.98 & 0.99 & 0.98 & 0.94 & 0.90 & 0.99 \\
\hline MEF & 0.98 & 0.95 & 0.93 & 0.90 & 0.84 & 0.56 & 0.71 & 0.94 \\
\hline $\mathrm{CD}$ & 1.07 & 1.05 & 1.07 & 1.05 & 1.14 & 1.16 & 0.98 & 1.08 \\
\hline \multicolumn{9}{|l|}{ Regression analysis } \\
\hline Estimate & -0.30 & 0.06 & 0.07 & -0.04 & 0.02 & -0.03 & 0.08 & -0.01 \\
\hline SE & 0.16 & 0.15 & 0.15 & 0.14 & 0.07 & 0.03 & 0.05 & 0.07 \\
\hline$P$-value $\left(\beta_{0}=0\right)$ & 0.07 & 0.69 & 0.61 & 0.75 & 0.68 & 0.32 & 0.09 & 0.93 \\
\hline \multicolumn{9}{|l|}{ Slope $\left(\beta_{1}\right)$} \\
\hline Estimate & 1.02 & 1.00 & 1.01 & 0.98 & 1.00 & 0.93 & 1.03 & 1.02 \\
\hline SE & 0.02 & 0.03 & 0.03 & 0.04 & 0.05 & 0.08 & 0.04 & 0.03 \\
\hline$P$-value $\left(\beta_{1}=1\right)$ & 0.12 & 0.91 & 0.59 & 0.72 & 0.85 & 0.41 & 0.38 & 0.54 \\
\hline \multicolumn{9}{|c|}{ MSEP source, \% MSEP } \\
\hline Mean bias & 2.39 & 6.36 & 20.67 & 8.14 & 16.01 & 21.51 & 65.10 & 9.68 \\
\hline Systematic bias & 6.47 & 1.46 & 2.64 & 1.04 & 3.80 & 3.63 & 2.58 & 3.31 \\
\hline Random error & 91.13 & 92.61 & 76.68 & 90.81 & 80.18 & 74.85 & 32.32 & 87.00 \\
\hline \multicolumn{9}{|l|}{ Root MSEP } \\
\hline Estimate & 0.09 & 0.09 & 0.11 & 0.11 & 0.01 & 0.01 & 0.03 & 0.02 \\
\hline$\%$ of the mean & 3.22 & 5.89 & 7.00 & 9.18 & 7.57 & 35.19 & 14.38 & 5.06 \\
\hline
\end{tabular}

${ }^{1}$ Obs: observed evaluation data set; CCC: concordance correlation coefficient; $\mathrm{Cb}$ : bias correction factor; MEF: modelling efficiency; CD: coefficient of model determination; MSEP: mean square error of the prediction; EBW: empty body weight (kg); HCW: hot carcass weight (kg); CCW: cold carcass weight (kg); TST: total soft tissues (muscle + fat, kg); BON: bone tissues (kg);

IF: internal fat (kg); VIS: organs and viscera (kg); OFF: offals ( $\mathrm{kg})$. 

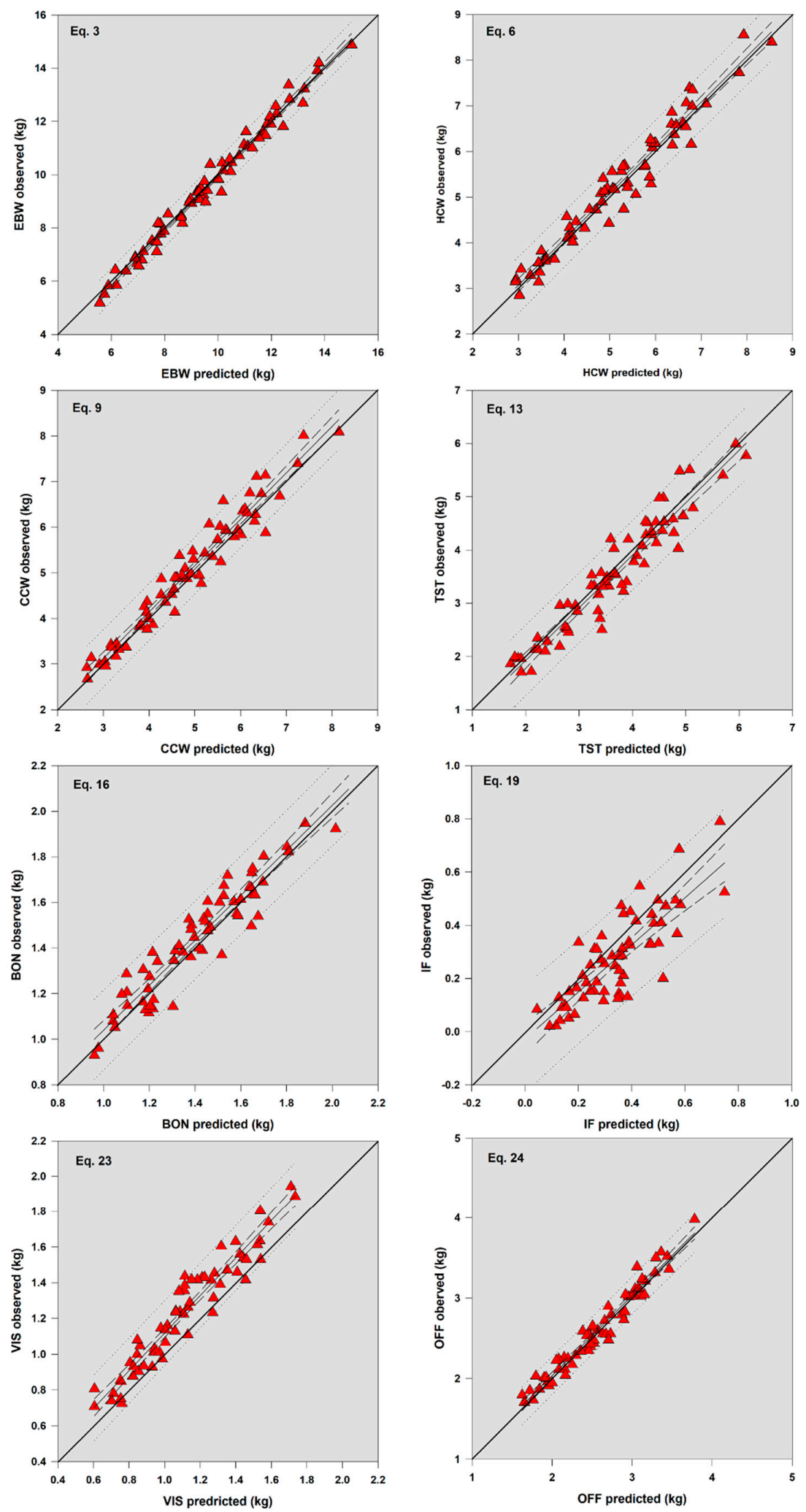

Figure 2. Relationship between observed and predicted values of carcass traits in suckling hair lambs.

\section{Conclusions}

The equations for predicting shrunk body weight (SBW), hot carcass weight (HCW), and cold carcass weight (CCW) using BMs had an $r^{2}$ ranging from 0.89 to 0.99 , and those for predicting the 
weights of the total soft tissues (TST) and bone tissues (BON) had an $r^{2}$ ranging from 0.74 to 0.91 . According to the evaluation parameters, these equations have satisfactory accuracy. Hence, the use of BMs could accurately and precisely be used as a useful and practical tool for predicting carcass characteristics of hair sheep lambs.

Author Contributions: Conceptualization, E.B.-D., J.A.M.-S., and A.J.C.-C.; methodology, E.B.-D., J.A.M.-S., and A.J.C.-C.; software E.B.-D., L.O.T., and J.H.-C.; validation, E.B.-D., J.A.M.-S., A.J.C.-C., and E.V.-B.-P.; formal analysis, E.B.-D., L.O.T., and A.J.C.-C.; investigation, E.B.-D., J.A.M.-S., and A.J.C.-C.; resources, A.J.C.-C., A.C.-H., and A.G.-V.; data curation, E.B.-D., J.H.-C., A.J.C.-C., and E.V.-B.-P.; writing-original draft preparation, E.B.-D., J.A.M.-S., A.J.C.-C., H.A.L.-R., and E.V.-B.-P.; writing-review and editing, E.B.-D., L.O.T., A.J.C.-C., H.A.L.-R., and E.V.-B.-P.; visualization, E.B.-D., J.H.-C., and E.V.-B.-P.; supervision, A.J.C.-C., A.C.-H., and A.G.-V.; project administration, A.J.C.-C.; funding acquisition, A.J.C.-C., A.C.-H., and A.G.-V. All authors have read and agreed to the published version of the manuscript.

Funding: This research was funded bythe Programa de Fomento a la Investigación through the project 'Eficiencia energética madre/cría en ovinos de pelo' (PFI: UJAT-DACA-2015-IA-02).

Acknowledgments: The authors want to thank Jose Manuel Piña Gutiérrez, who provided the facilities of 'El Rodeo' Ranch. The authors are also grateful for the research grant provided by the Programa de Fomento a la Investigación through the project 'Eficiencia energética madre/cría en ovinos de pelo' (PFI: UJAT-DACA-2015-IA-02). The first author is grateful for the research grant provided by the National Council of Science and Technology of Mexico (CONACYT) for his postgraduate studies at the Universidad Juárez Autónoma de Tabasco, Mexico.

Conflicts of Interest: The authors state that there are no conflict of interest.

\section{References}

1. Scholz, A.M.; Bünger, L.; Kongsro, J.; Baulain, U.; Mitchell, A.D. Non-invasive methods for the determination of body and carcass composition in livestock: Dual-energy X-ray absorptiometry, computed tomography, magnetic resonance imaging, and ultrasound: Invited review. Animal 2015, 9, 1250-1264. [CrossRef] [PubMed]

2. Chay-Canul, A.J.; Magaña-Monforte, J.G.; Chizzotti, M.L.; Piñeiro-Vázquez, A.T.; Canul-Solís, J.R.; Ayala-Burgos, A.J.; Ku-Vera, J.C.; Tedeschi, L.O. Energy requirements of hair sheep in the tropical regions of Latin America. Review. Rev. Mex. Cienc. Pecu. 2016, 7, 105-125. [CrossRef]

3. Chay-Canul, A.J.; Sarmiento-Franco, L.S.; Salazar-Cuytún, E.R.; Tedeschi, L.O.; Moo-Huchin, V.; Canul Solís, J.R.; Piñeiro-Vázquez, A.T. Evaluation of equations to estimate fat content in soft tissues of carcasses and viscera in sheep based on carbon and nitrogen content. Small Rumin. Res. 2019, 178, 106-110. [CrossRef]

4. Morales-Martínez, M.A.; Arce-Recinos, C.; Mendoza-Taco, M.M.; Luna-Palomera, C.; Ramírez-Bautista, M.A.; Piñeiro-Vazquez, A.T.; Vicente-Perez, R.; Tedeschi, L.O.; Chay-Canul, A.J. Developing equations for predicting internal body fat in Pelibuey sheep using ultrasound measurements. Small Rumin. Res. 2020, 183, 106031. [CrossRef]

5. Aguilar-Hernández, E.; Chay-Canul, A.J.; Gómez-Vázquez, A.; Magaña-Monforte, J.G.; Ríos, F.G.; Cruz-Hernández, A. Relationship of ultrasound measurements and carcass traits in Pelibuey ewes. J. Anim. Plant Sci. 2016, 26, 325-330.

6. Castilhos, A.M.; Francisco, C.L.; Branco, R.H.; Bonilha, S.F.M.; Mercadante, M.E.Z.; Meirelles, P.R.L.; Pariz, C.M.; Jorge, A.M. In vivo ultrasound and biometric measurements predict the empty body chemical composition in Nellore. J. Anim. Sci. 2018, 96, 1678-1687. [CrossRef] [PubMed]

7. Ribeiro, F.R.B.; Tedeschi, L.O.; Rhoades, R.D.; Smith, S.B.; Martin, S.E.; Crouse, S.F. Evaluating the application of dual X-ray energy absorptiometry to assess dissectible and chemical fat and muscle from the 9th-to-11th rib section of beef cattle. Prof. Anim. Sci. 2011, 27, 472-476. [CrossRef]

8. Bautista-Díaz, E.; Salazar-Cuytun, E.R.; Chay-Canul, A.J.; García-Herrera, R.A.; Piñeiro-Vázquez, A.T.; Magaña-Monforte, J.G.; Tedeschi, L.O.; Cruz-Hernández, A.; Gómez-Vázquez, A. Determination of carcass traits in Pelibuey ewes using biometric measurements. Small Rumin. Res. 2017, 147, 115-119. [CrossRef]

9. Juárez, M.; López-Campos, Ó.; Roberts, J.C.; Prieto, N.; Larsen, I.L.; Uttaro, B.; Dugan, M.E.R.; Cancino-Baier, D.; Hosford, S.; Galbraith, J.; et al. Exploration of methods for lamb carcass yield estimation in Canada. Can. J. Anim. Sci. 2018, 98, 760-768. [CrossRef] 
10. Alves, A.A.C.; Pinzon, A.C.; da Costa, R.M.; da Silva, M.S.S.; Vieira, E.H.M.; de Mendonça, I.B.; Viana, V.S.S.; Lôbo, R.N.B. Multiple regression and machine learning based methods for carcass traits and saleable meat cuts prediction using non-invasive in vivo measurements in commercial lambs. Small Rumin. Res. 2019, 171, 49-56. [CrossRef]

11. Janiszewski, P.; Borzuta, K.; Lisiak, D.; Grzéskowiak, E.; Stanislawski, D. Prediction of primal cuts by using an automatic ultrasonic device as a new method for estimating a pig-carcass slaughter and commercial value. Anim. Prod. Sci. 2019, 59, 1183-1189. [CrossRef]

12. Barba, L.; Sánchez-Macías, D.; Barba, I.; Rodríguez, N. The potential of non-invasive pre- and post-mortem carcass measurements to predict the contribution of carcass components to slaughter yield of guinea pigs. Meat Sci. 2018, 140, 59-65. [CrossRef] [PubMed]

13. Ramos, I.O.; Gonçalves de Rezende, M.P.; Carneiro, P.L.S.; de Souza, J.C.; Sereno, J.R.; Bozzi, R.; Malhado, C.H.M. Body conformation of Santa Inês, Texel and Suffolk ewes raised in the Brazilian Pantanal. Small Rumin. Res. 2019, 172, 42-47. [CrossRef]

14. Arcos-Álvarez, D.; Canul-Solís, J.; García-Herrera, R.; Sarmiento-Franco, L.; Piñeiro-Vazquez, Á.; Casanova-Lugo, F.; Tedeschi, L.O.; Gonzalez-Ronquillo, M.; Chay-Canul, A. Udder Measurements and Their Relationship with Milk Yield in Pelibuey Ewes. Animals 2020, 10, 518. [CrossRef]

15. Chay-Canul, A.J.; García-Herrera, R.A.; Salazar-Cuytún, R.; Ojeda-Robertos, N.F.; Cruz-Hernández, A.; Fonseca, M.A.; Canul-Solís, J.R. Development and evaluation of equations to predict body weight of Pelibuey ewes using heart girth. Rev. Mex. Cienc. Pecu. 2019, 10, 767-777. [CrossRef]

16. Canul-Solis, J.; Angeles-Hernandez, J.C.; García-Herrera, R.A.; Razo-Rodríguez, D.; del Razo-Rodríguez, Lee-Rangle, H.A.; Piñeiro-Vazquez, A.T.; Casanova-Lugo, F.; Rosales-Nieto, C.A.; Chay-Canul, A.J. Estimation of body weight in hair ewes using an indirect measurement method. Trop. Anim. Health Prod. 2020. [CrossRef]

17. Del Salazar-Cuytun, E.R.; Chay-Canul, A.J.; Ptáček, M.; García-Herrera, R.A.; de Rivera-Alegría, F.M.; Aguilar-Caballero, A.J.; Sarmiento-Franco, L.A. Relationship between body mass index and body condition score in Pelibuey ewes. Ecosistemas Recur. Agropecu. 2020, 7, e2474. [CrossRef]

18. SAS 9.3 Software; Institute Inc.: Cary, NC, USA, 2010.

19. Tedeschi, L.O. Assessment of the adequacy of mathematical models. Agric. Syst. 2006, 89, 225-247. [CrossRef]

20. Fonseca, M.A.; Tedeschi, L.O.; Valadares-Filho, S.C.; De-Paula, N.F.; Silva, L.D.; Sathler, D.F.T. Evaluation of equations to estimate body composition in beef cattle using live, linear and standing-rib cut measurements. Anim. Prod. Sci. 2017, 57,378-390. [CrossRef]

21. Cochran, W.G.; Cox, G.M. Experimental Design; John Wiley \& Sons: New York, NY, USA, 1957.

22. Loague, K.; Green, R.E. Statistical and graphical methods for evaluating solute transport models: Overview and application. J. Contam. Hydrol. 1991, 7, 51-73. [CrossRef]

23. Mayer, D.G.; Butler, D.G. Statistical validation. Ecol. Model. 1993, 68, 21-32. [CrossRef]

24. Lin, K. A concordance correlation coefficient to evaluate reproducibility. Biometrics 1989, 45, $255-268$. [CrossRef]

25. Bonilha, S.F.M.; Tedeschi, L.O.; Packer, I.U.; Razook, A.G.; Nardon, R.F.; Figueiredo, L.A.; Alleoni, G.F. Chemical composition of whole body and carcass of Bos indicus and tropically adapted Bos taurus breeds. J. Anim. Sci. 2011, 89, 2859-2866. [CrossRef] [PubMed]

26. Tedeschi, L.O.; Fox, D.G.; Kononoff, P.J. A dynamic model to predict fat and protein fluxes associated with body reserve changes in cattle. J. Dairy Sci. 2013, 96, 2448-2463. [CrossRef] [PubMed]

27. Hernandez-Espinoza, D.F.; Oliva-Hernández, J.; Pascual-córdova, A.; Hinojosa-Cuéllar, J.A. Descripción de medidas corporales y composición de la canal en corderas Pelibuey: Preeliminar study. Rev. Cient. 2012, 22, 24-31.

28. Shehata, M.F. Prediction of live body weight and carcass traits by some live body measurements in Barki lambs. Egypt. J. Anim. Prod. 2013, 50, 69-75.

29. Rashad, A.M.A.; EL-Hedainy, D.K.; Mahdy, A.E.; Badran, A.E.; El-Barbary, A.S.A. Utilization of live body weight, measurements, and eye muscle components to predict carcass performance of fattened Egyptian male buffalo calves. Trop. Anim. Health Prod. 2019, 51, 2405-2412. [CrossRef]

(C) 2020 by the authors. Licensee MDPI, Basel, Switzerland. This article is an open access article distributed under the terms and conditions of the Creative Commons Attribution (CC BY) license (http://creativecommons.org/licenses/by/4.0/). 